\title{
Nation-building as epistemic violence
}

Ye Hui

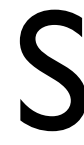

ince the People's Republic of China (PRC) declared a 'People's War on Terror' (反恐人民战争) in 2014 in the wake of a series of violent incidents perpetrated by or associated with Uyghurs, the Chinese authorities have built an extensive surveillance, internment, and forced-labour regime to control the non-Han peoples in Xinjiang. In a sweeping fashion, the Chinese Party-State has criminalised the everyday lives of Muslims in Xinjiang (Byler 2019). In profiling entire non-Han peoples as potential 'terrorists', the campaign has been an act of Han-majoritarian state violence. While this has often been interpreted in an essentialist fashion, as indicative of the authoritarian nature of the Party-State, transnationally minded scholars (many of whom have contributed to this volume) have shown that this perspective obscures the violence of Islamophobia and global racial capitalism, neither of which is unique to China (Brophy 2019; Byler 2021; Liu 2020). We cannot understand the particular repression of Muslims in Xinjiang without investigating the globalised logic of the modern age: capitalism and so-called progress often mean policing, exploitation, and dehumanisation for those on the receiving end.

However, while it is crucial to situate the current state violence towards Turkic Muslims at the intersection of postsocialist neoliberal development in inner Asian frontiers since the 1990s and the heightening of Islamophobia due to the West's 'War on Terror', I suggest we also view the tragedy as part of the centuries-long global imperial history. The epistemic infrastructure for this political violence was established through modern imperialism and has been reproduced by the nation-state-even when the latter was born of a history of anti-imperialism, such as the PRC. The Chinese state's dispossession of Turkic Muslims today is an effect of secular nation-building. The nation-state is an incessant, violent project that began to be globalised in 1492 with two simultaneous developments: within Europe, the Castilian monarchy forced exile and conversion on Jews and Muslims to build a pure nation-state for Christian Spaniards; overseas, the same Spanish state conquered the Americas through genocide and conversion (Mamdani 2020). In other words, ethnic cleansing 
and conquest lie at the heart of the myth of national progress. While the violence in Xinjiang is particular to both the postsocialist context and China's role in a post-9/11 global security regime that targets racialised bodies, it must also be understood as continuous with technologies of imperialism that have transposed non-nationalist polities, such as Qing China, into nation-states.

This essay traces a paradigm shift in political rationality from the late Qing Empire to modern China with respect to the 'new frontier' (新疆). In the Qing's violent encounters with Western and Japanese imperial powers, and as the Manchu emperors of the Qing struggled to maintain authority, an emergent group of Han elites in the multiethnic empire began to reconceptualise the political community. Territorial integrity and a cultural-if not racial/ethnic - homogeneity, for the first time, became the principal conceptual grids through which early nationalists imagined a political community of 'China', the nation-state (Duara 1995; Millward 1998; Mosca 2013). This epistemic shift is paradoxical: it enabled Chinese nationalists to articulate anti-imperialist self-determination, but only on imperially conscripted terms. It was only on this altered epistemic ground of the nation-state that Chinese nationalists came to perceive Turkic Muslims in Xinjiang as a problem. As the nationalist pedagogy has hardened since the 1990s, it becomes increasingly difficult for Turkic Muslims - their inherited life-worlds and political actions-to be taken seriously on their own terms. Dissent is narrowly interpreted as a threat to national unity and territorial sovereignty, thereby justifying automated, widespread systems of surveillance and dispossession. Yet this violent positioning is not inevitable. By focusing on the epistemic (and material) violence of the nation-state, my intention is not to reinscribe closure, but to scrutinise the paradoxes, contingencies, and tragedies of nation-building. This is also an invitation to unlearn the progressive temporality on which colonial and nationalist regimes of violence have been founded, so we can look for other ways towards collective action.

\section{Territory and population as the sovereign body}

After the Qing annexation of what became Xinjiang in 1759, the empire did not imagine itself as a civilising project to bring 'Chinese' order and virtues to the Muslim peoples of Altishahr. Rather, the Qing imperial house, not 'China', was at the centre of this premodern political imagination, under which Han, Manchu, Mongol, Tibetan, and Muslim were 
the five main cultural blocs equal 'under Heaven' (天) and 'in great unity' (大同) (Millward 1998: 197-201). Until 1864, Manchu and Mongol officials governed local communities through alliances with local Muslim elites, serving as intermediaries and seeking to shield locals from the destabilising influence of Han merchants and settlements (Millward 1998). However, as the Qing became encircled by sprawling British and Russian imperialisms in Asia from the mid-eighteenth century, and later the French threat from the southwest and the Japanese menace from the coast, their old way of comprehending the frontiers became unworkable. They could no longer see frontier crises as place-specific, discrete, and too complex to be standardised into a centralised lexicon, especially when the British Empire operated simultaneously on multiple frontiers (Mosca 2013). Pervasive geopolitical upheavals pushed Han scholars and officials who later dominated the high offices of the Qing to reconceptualise the empire, for the first time, as an integrated territorial entity in need of 'grand strategies' to be on par with what came to be perceived as its rival states (Mosca 2013: 11).

The shift towards imagining the Qing as a self-contained entity among other hostile geopolitical entities is reflected in an important debate in 1874 between two Han statesmen, Zuo Zongtang (1823-1901) and Li Hongzhang (1812-85), which led to the reconquest and integration of Xinjiang into a modernising Qing state. Both sides deployed a metaphor of the sick body to convey the danger of foreign imperial threats, although they disputed which threat (inner frontier or coastal) constituted a disease of the heart and hence directly endangered the life of the state (Millward 2007: 126-27). Corporeal metaphors had long been deployed in traditional Confucian political thought; they were embedded in a premodern mode of social organisation - what Benedict Anderson (2006) has termed 'the religious community' and 'the dynastic realm'. Under such a premodern form of sovereignty, society is organised vertically around 'a high centre whose legitimacy derives from divinity, not from populations' (Anderson 2006: 19); nor does political legitimacy derive from territory. We can see the importance of territory emerge in the changing conceptualisation of the body politic. In Confucian cosmopolitical order, the political body would be considered ill because of immoral and corrupt rule. It would be the duty of the Confucian literati to restore it to health. However, in response to China's encounter with Western and Japanese imperialisms, the metaphor of the body was territorialised. According to the then emergent nationalist rationality, losing claim to a frontier territory amounted 
to political dismemberment or even death. Overlapping and changing sovereignty over the borderland hence became problematic. Territory must be permanently defended. As Chinese President Xi Jinping expressed to then US Defence Secretary Jim Mattis in 2018: 'We cannot even lose one inch of territory left behind by our ancestors. What is other people's we do not want at all' (Stewart and Blanchard 2018).

While this new political rationality enabled Qing scholars and officials to comprehend and respond to foreign imperialist challenges, it also subjugated complex spaces and overlapping sovereignty to empire-wide strategic considerations. Conceptualising the Qing Empire (hence 'China') as a self-contained territory unambiguously demarcated from its rival states has had devastating effects on the frontier peoples and places, for their complex, and hence impure, orientations and loyalties became objects of permanent suspicion and surveillance. The point of foregrounding this epistemic disjuncture is not to idealise the early Qing and its conquests. Rather, I seek to show that, for centuries before modern imperialism globalised the nation-state paradigm, people were not required to have the same culture, language, or values to share a world; the land they lived on did not have to be permanently reified as a fixed, sovereign geo-body for sociopolitical life to be meaningful.

While Han scholars had presented economic arguments for integrating Xinjiang to ease the burden of overpopulation in China proper as early as 1826 (Millward 1998: 243), the proposal was only given new legitimacy under the epistemic paradigm of the modern state. As the Qing was shuffled through the era of New Imperialism (1870-1914), its emergent epistemic infrastructure of the modern state engendered not just discursive shifts, but also material and institutional reforms. After the 1878-81 reconquest, Zuo Zongtang proposed establishing a Xinjiang province. The court authorised Zuo, with his Han officials and armies, to replace the multiple indirect systems of local authorities with Chinese-style administration (郡县), to integrate Xinjiang into China proper (Millward 2007: 132). The assumption underlying the series of integrationist policies across multiple frontiers-such as promoting Han migration and training non-Han elites in Confucian schools for magistrate positions-was that, to make frontier regions governable, they had to be demographically and culturally more like the Han-dominated China proper (Millward 2007: 138). At this moment, the Muslimness of the Turkic peoples was not seen as oppositional to 'Chineseness.' The Sinicising agenda was to make 
Turkic-speaking peoples-first, the elites and, later, the commoners-into morally Confucian Muslims, so they could become more loyal to the throne (Schluessel 2020). The Confucian pedagogy was short-lived and unsuccessful, lasting only until the Qing was overthrown in 1911. But the Sinicising and modernising mission pioneered by Zuo Zongtang continued into the twentieth and twenty-first centuries, and acquired new, deadly force when married with a change in temporal horizons. As linear, progressive time swept through the epistemic ground of late-Qing elites via new social-scientific concepts, and the concept of minzu (民族, usually translated as 'nation', 'nationality', 'race', or 'ethnicity') arrived from Japan, the Central Asian Muslims and their temporalities came to be rendered distant and Other, while the territory in which they lived was being integrated into an imagined sovereign body of China.

\section{The social scientific and the aporia of minzu: Separate and the same}

The ambiguity of the concept minzu has long haunted Chinese nationalism. The term was first introduced from the Japanese word minzoku (itself a neologism for the German word Volk, meaning 'people' or 'nation') in the early 1900s, after the Qing's alarming defeat in the First Sino-Japanese War (1894-95) (Leibold 2006: 213). Han revolutionaries in the late Qing began to use this concept as a new epistemic ground for their anti-Qing activism. The old culturalist distinction between Han and Manchu was insufficient to justify their opposition to a royal house that had successfully assimilated itself into the Confucian and other ritual institutions (Mullaney 2010: 23). Revolutionaries promoted the concepts of Hanzu (汉族) and Manzu (满族) as unassimilable racial categories and framed their opposition as a majority race's struggle against a conquering minority race (Duara 1995: 37). After the Qing were overthrown in 1911, the Nationalists of the Guomindang (国民党, GMD) found the discourse of a racially pure Han China inexpedient, as the same nation-race equation had fuelled growing self-determination movements in the former inner Asian frontiers, which they had no intention of relinquishing. The solution for the GMD under the stewardship of Sun Yat-sen (1866-1925) was to extend the recognition of minzu status to the Manchu, Mongol, Hui, and Tibetan peoples alongside the Han and unify them into one people, so the frontier regions in which they lived could be incorporated into the new nation-state. 
Sun Yat-sen's theory of minzu offers a glimpse into the constitutive paradox of minzu and its propensity for majoritarianism. As Foucault has pointed out, modern statecraft in eighteenth-century Europe depended on 'the emergence of the problem of population', through which statistics and other social-scientific practices became central to the legitimation and exercise of political power (Chakrabarty 2002: 83-91). The very idea of good government-fairness and justice in political representation-relies on mathematical notions of enumeration and proportionality. In the age of calculability, a numerically larger community carries more political weight. In Sun's famous 1924 lecture on nationalism, he maintained that minzu was a community that shared five common traits: blood, religion, language, economy, and customs. What about the Tibetans, Mongols, Manchu, Turkic, and other peoples who might not share these traits with the Han? Sun dismissed them as numerically insignificant: 'The “non-natives" [外来] merely make up less than ten million. We can say that the four hundred million Chinese people are entirely Hanzu: sharing a common blood, common language, common religion, and common customs-a single, pure minzu' (Sun 2006). Measured through the statistical apparatus of population, the theoretical equality between minzu promised by the new Republic of China failed to bring real equality. Rather, because everyone was equal regardless of minzu-that is, statistically the same-the numerical majority became politically privileged.

As the Japanese invasion and annexation of Manchuria broke into a fullscale war with the Republic of China in 1937, the GMD and the Chinese Communist Party (CCP) came to a critical convergence through which the theory of minzu and its contradictions began to be put into practice. Before 1937, the CCP, under the tutelage of the Communist International, was committed to the rights to self-determination of non-Han peoples, setting itself apart from the GMD's 'great Han chauvinism' (大汉族主 义). This period marked a pivotal transformation of the CCP from a marginal oppositional movement that had been critical of the GMD's assimilationist minzu policies, to a nationalist rival with similar goals as the GMD. During the Second United Front (1937-45), the two parties agreed on the notion of China-that is, the sovereignty of the Republic of China over all former Qing territories except the already independent Mongolia - and the imperative to defend it against Japan. They also agreed that during the war, it was necessary to centre the representation 
of the Chinese nation (中华民族) both despite (from the communist internationalist perspective) and through (from the CCP and GMD nationalist perspective) the unambiguous privileging of the Han in this imagination. It was the only way to mobilise the numerical majority to join the resistance movement (Liu 2018: 122).

Hence, they faced a challenge: how to stretch the narrow skin of an apparently Han-centric representation over immense ethnocultural and political diversity? Meanwhile, Japanese scholars and agents were tirelessly coopting non-Han elites in the frontier regions to install anti-Han nationalist regimes under Japanese imperial patronage (Leibold 2006). Their persuasive strategies relied on theories of ethnic-racial distinction between the Manchus, Mongols, Hui, and so on, on one hand, and the Han on the other, drawing on modern scientific disciplines such as history, anthropology, and archaeology to authenticate their claims of different national origins from the Han (Leibold 2006).

This strategy of divide/define and conquer incited seemingly opposite but equally nationalistic responses from the GMD and the CCP as both sought to derive legitimacy from the social sciences. The Nationalist regime blended the scientific theory of race with a revised myth of ancestry according to which the Mongols, Manchu, Tibetans, and Muslims, along with the Han, were all descendants of the mythical Yellow Emperor (黄帝), who was (and is) commonly believed to be the progenitor of the Han. By stretching the narrative of a common ancestor, the GMD regime justified assimilationist policies as a project of reunion (Mullaney 2010:28).

The Communists objected to this single-race theory as unscientific and Han chauvinistic (Chen 1943, quoted in CCP UFWD 1991). Yet having recognised the sovereignty of the Nationalist regime over all former Qing territory, the CCP was ultimately constrained. It could advocate only for a plural singularity of the nation-state by recognising non-Han communities as 'the minority minzu' (少数民族) and not plural political formations such as federalism. This was evident in their discursive shift on the minority question. In the 1931 Constitution of the Chinese Soviet Republic, the CCP proclaimed that it 'categorically and unconditionally recognizes the right of minority minzu to self-determination', which included the right of independence (quoted in Mullaney 2010: 26). In 1938, Mao Zedong announced in his report titled 'On the New Phase' (论新阶段) that the CCP 
allows the Mongol, Hui, Tibetan, Miao, Yao, Yi, Fan, and other minzu to have equal rights as the Han, and based on the principle of a united anti-Japanese front, have the rights to manage its own affairs, and to ally with the Han to build a unified state. (Mao 1938)

The CCP in 1938 was no longer a marginal revolutionary movement that acceded to the minority right of self-determination to undermine the legitimacy of the Republican state. Under duress from the GMD onslaughts, the Soviet reluctance to provide aid, the alienation in non-Han communities during the Long March (1934-36), and Japanese imperialism, the CCP changed strategies and positioned itself as a spokesperson of the state and official nationalism: it conditionally granted the minority minzu recognition and autonomy, but only if they performed the required duties as national minorities, meaning, conditionally sovereign and less-than-sovereign minorities.

Furthermore, the CCP's anti-imperialist struggle was imperially conscripted in its very efforts to recognise 'the minority minzu' as distinct categories and build an inclusive, progressive nation. In addition to statistics, the CCP shared another set of social-scientific premises with the imperial powers it sought to subvert. The epistemic ground that enabled modern practices of definition (such as the minzu classification) is well articulated by the anthropologist Johannes Fabian's (2014: 27) genealogy of naturalised Time in European conceptual-colonial history-that is, 'the classification of entities or traits which first have to be separate and distinct before their similarities can be used to establish taxonomies and developmental sequences. This presupposed essential separation and distance between 'primitive' and 'civilised' societies have been the justification for colonial plunder and conversion. What is more tragic is that communist regimes reproduced such violence in the name of anti-imperialism. In 1949, Joseph Stalin urged the CCP leadership to occupy Xinjiang immediately to keep the British from activating the Muslims against the Chinese communists, 'for there are large deposits of oil and cotton in Xinjiang, which China needs badly' ('Memorandum ...' 1949). While repudiating the crude racism of the West, the Soviet and Chinese communists upheld the same 'primitive or civilised' distinction. Like European colonists, the communist state-builders viewed indigenous peoples as incapable of self-rule, their land available for occupation, and their resources ready for extraction. 
When this boundary-drawing exercise is recruited to do the work of imperial domination and, ironically, anti-imperial nationalism, the aporia for the colonial civilising mission and national incorporation is continuous. Hui, Mongol, Uyghur, and Han had to be first objectified as distinct, self-contained entities (the non-Han represented as backward vis-a-vis the Han) before their contacts and exchanges could be used to establish developmental sequences of ethnic melding and unity, thereby establishing the necessity of the CCP leadership in bringing about the historically inevitable progress (CCP UFWD 1991). Unity, therefore, no matter how passionately represented, is always subjected to suspicion. How can fundamentally separate and distinct entities be truly unified as one? Surely some Tibetans or Mongols or Uyghurs still harbour their parochial loyalties and must be constantly surveilled and purified into transcendent citizens of China? The impossible task of the nation-state is to define permanent difference and rule it to its extinction. By accepting separation as the premise of diversity and progress as the universal temporality, the Communists did not just appropriate imperial tools for emancipatory ends. Their political formations were too powerfully altered by the imperial epistemic infrastructure. Tragically, since the CCP came to power in 1949, their imperially constrained political rationalities have reproduced the hierarchical distinction between the self and the Other, the majority and the minority - an underlying epistemic infrastructure that has made conceivable the mass detention, surveillance, and control of Turkic Muslims in Xinjiang today.

\section{Unlearning progress}

In a press conference on 26 March 2021, China's Foreign Ministry spokesperson Hua Chunying denounced the US charge of genocide in Xinjiang by invoking precedents of US imperial wars waged in the name of human rights:

[The United States'] true intention is to undermine China's security and stability and stop China from growing stronger. We solemnly inform the US side that today's China is neither Iraq nor Syria, still less the late Qing Dynasty downtrodden by the Eight-Power Allied Forces ... We have full resolution, determination and capability to firmly defend national sovereignty, security, dignity, and honour. (Hua 2021) 
I am deeply pained by this statement because my ancestors were survivors of imperial and nationalist wars. This proud proclamation of counterhegemony is authorised by progress. Yet progress is entangled in separation, competition, and domination. Must China be not Iraq, not Syria, and not the late Qing to defend 'sovereignty, security, dignity, and honour'? Do the multitudes of communities in and of Iraq, Syria, and the Qing not deserve safety and sanctity? Do the displacement and destruction of their life-worlds-which are also our shared, entangled life-worlds-not demand outrage and mourning? How are some of us infuriated only because China has become the second strongest yet still cannot win the game, but not because the game of the nation-state itself is unjust and rooted in long-run imperial histories?

As Talal Asad (2003) has argued, secular modernity has to do with a radical change in the distribution of pain and the rationality that justifies it. Modern cruelties of warfare, colonisation, incarceration, and forced labour are normalised by 'a secular calculus of utility and a secular dream of happiness' (Asad 2006: 508). Just as the US invasion of Afghanistan was justified by the mission to 'save' Afghan women from (allegedly anti-modern) Islamic patriarchy, the PRC has rationalised its cruelties towards the Turkic Muslims today as 'saving' the Muslim masses (women and children in particular), who are seen as pawns of 'separatism, extremism, and terrorism'-simply because they have been defined as not Han, and hence, not safely Chinese. Since the ascendancy of the modern state, the pain inflicted by secularism and nation-building has been justified as necessary for the elimination of what is seen as excessive, backward 'religious' and 'traditional' pain. Yet, as made evident by both the US occupation of and withdrawal from Afghanistan and the Xinjiang camps, the violence of civilisation is enmeshed in-and hence deserves no less scrutiny than-the violence of so-called backwardness. Ultimately, liberal and communist regimes are not so far apart on the secular calculation of pain and gain.

In situating the present state terrorism in Xinjiang within the longer-run history of imperial epistemic violence that has underpinned Chinese nationalism and modernity, I seek to de-exceptionalise China and gesture to the difficult yet not impossible task of decolonising the political. While early Chinese communism has its specificities, its reproduction of imperial technologies of violence should be viewed as part of the shared paradoxical struggles in many postcolonial contexts. The CCP's impasse is not unlike how European settler-colonial regimes first denied colonised subjects 
the recognition and rights of nationhood, and then granted them the recognition, but without altering colonial regimes of domination (Massad 2018). As David Scott (1999: 45) has noted in another context, as in the seventeenth-century colonial reforms in Ceylon (present-day Sri Lanka) that allowed certain colonised subjects to participate in representative institutions,

the crucial point here is not whether natives were included or excluded so much as the introduction of a new game of politics that the colonized would (eventually) be obliged to play if they were to be counted as political.

As important as it is to hold the Chinese state accountable, my goal is less to critique the PRC than to reflect on how the political itselfnamely, nation-state formation-is an effect of colonisation. Perhaps, by revealing the peculiar epistemic apparatus of imperially conscripted nationalism - that territory must be defended, the population homogenised, and communities separated and objectified-we are able to see China's anti-imperialism as reenacting the founding epistemic and material violence of the modern nation-state. It is time to look for another way. 
This text is taken from Xinjiang Year Zero, edited by Darren Byler, Ivan Franceschini and Nicholas Loubere, published 2022, The Australian National University, Canberra, Australia.

doi.org/10.22459/XYZ.2021.01 